\section{Richard Alfred Moncrief}

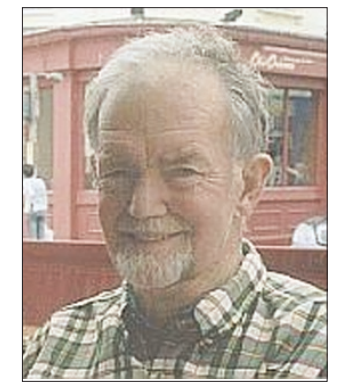

My father, Richard Moncrief, passed away after a long illness on Friday 18 February 2005, in Leicester Royal Infirmary.

Richard was born on 18 June 1931 in Louth, Lincolnshire, the son of Alfred and Ena. Along with Janet, his younger sister, they lived in Chapel St. Leonards and later on in Skegness, where Richard attended Skegness Grammar School.

He did his National Service in the RAF in 1948 and then followed in his father's footsteps into the fire service, where he was stationed at Lancaster Place, in Leicester, for five years. He gained a distinction in the Institute of Fire Engineers examination but decided, however, on a change of career and commenced his studies at Dundee School of Dentistry, (University of St. Andrews), in 1955.

It was here that, at a Union dance in 1956, he spotted Ann whom he fell in love with and married in 1959.

On qualifying in 1960 Richard worked in Dundee with Dr Robert (Bobby) Whyte for a year, thereafter moving south to Cannock to work with Stan Bollington and Tony Lynes for two years. In 1962 Ann gave birth to their first child, Andrew. Richard soon decided that he wanted to run a practice of his own and began the search, which led to an opportunity in Leicester on the Welford Road. In July 1963 Richard and Ann started what was to become a very successful family dental practice.

More children were to follow, with Emily in 1963, Edward (myself) in 1967 and Vickie in 1971. It was in 1969 that Richard and Anne moved out from 'above the shop' to the established family home on London Road.

\section{Richard had a large list of happy patients that often included three generations of the same family.}

Richard's old university friend, and best man, Fred Stuart, joined Richard at the Welford Road practice in 1965 and was the first of many associates to have the privilege of working with my father. This included myself - after my own dental qualification from Sheffield in 1990 - and I worked alongside my father until his retirement from clinical dentistry in 2000.

Richard had a strong commitment to providing NHS dental care to the local community and he had a large list of happy patients that, by the end of his career, often included three generations of the same family. He worked hard and pushed his devoted staff to do likewise, but he was always fair and had a soft side that endeared him to those he drove the hardest.

Richard was equally as energetic in his spare time. He had part ownership of an Auster light aircraft (G-Alfa) and also enjoyed motor biking and windsurfing. On the sporting front he played football with his father as a youth and later enjoyed squash and skiing. In recent years he took up bridge.

Throughout his last years Richard bore his treatment courageously and his brave conduct filled me with the utmost pride. He is survived by wife Ann and four devoted children as well as seven wonderful grandchildren. He also leaves behind Elaine, a loyal companion of recent years.

E. Moncrief

\title{
Tony Woodward
}

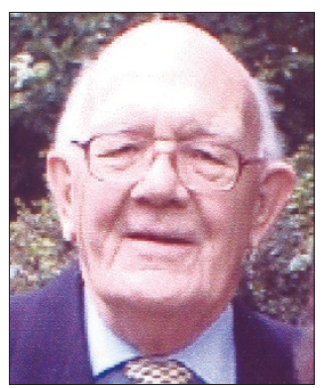

Tony Woodward, former RAF dental surgeon and general practitioner for 34 years, died at home on 24 January 2005. He was 85.

Born in Oswestry, Tony attended Oswestry School and Ellesmere College before moving to London to train at Guy's Hospital. Graduating in 1942, he served with the RAF for five years. He then returned home to Oswestry to join the family practice at Oswyn House. He was firmly committed to providing NHS dental care in the Oswestry area - and in the Ellesmere area, where he also held a surgery once weekly.

Throughout his life Tony worked tirelessly for the benefit of local medical establishments. In the 1960s he became a founder member of the League of Friends of Oswestry and District Hospital, the League of Friends of the Orthopaedic Hospital and the League of Friends of the Derwen College. He served as

\section{Tony worked tirelessly for the benefit of} local medical establishments...

Dental Surgeon to Derwen College from 1948-1982 and governor from 1984-2000. He was also a governor of the Oswestry Girls' High School and even found time to belong to Oswestry Rotary Club and the St Oswald Lodge of Freemasons - with whom he remained a member for 67 years.

Tony was devoted to his home town and was one of Oswestry's most distinguished and well known dentists. He will be sadly missed by wife Jane, sons Mark and Jonathon, daughters Zoe and Jill and all his grandchildren and greatgrandchildren. 